\title{
Dietary Intake of Vitamin A and Macronutrients among Pregnant Women in Ngaoundere Town, Adamawa Region, Cameroon
}

\author{
Damndja Wilfred Ngaha1, Edith N. Fombang1*, Richard Aba Ejoh ${ }^{1,2}$ \\ ${ }^{1}$ Department of Food Sciences and Nutrition, National School of Agro-Industrial Sciences, \\ University of Ngaoundere, Ngaoundere, Cameroon \\ ${ }^{2}$ College of Technology, University of Bamenda, Bambili, Cameroon \\ Email: ${ }^{*}$ edfombang@yahoo.fr
}

Received 18 September 2014; revised 6 October 2014; accepted 18 October 2014

Copyright (C) 2014 by authors and Scientific Research Publishing Inc.

This work is licensed under the Creative Commons Attribution International License (CC BY). http://creativecommons.org/licenses/by/4.0/

(c) (i) Open Access

\begin{abstract}
This paper examines the risk of Vitamin A deficiency among selected pregnant women in Ngaoundere, Adamawa Region, Cameroon. A total of one hundred (100) pregnant women attending ante natal visits at the Regional Hospital in Ngaoundere were involved in a survey conducted in 2012 which used a 24-hour dietary recall to assess their dietary intake. Food models were used to assist memory and portion sizes of food taken. Carotenoids were quantified in the meals commonly consumed, as well as proteins, sugar, fibers and oil, nutrients intervening in carotenoids absorption and Vitamin A metabolism. The results indicated that the dietary intake of Vitamin A was inadequate with $37.5 \%$ of the selected pregnant women exposed to acute Vitamin A deficiency, while $20 \%$ of them were exposed to the severe form. The daily consumption of Vitamin $A$ was about $539.09 \pm 43.09 \mu \mathrm{g}$, corresponding to a contribution of $67.39 \%$ to the Vitamin A requirement of the pregnant women. The dietary intake of macronutrients was also inadequate with a daily consumption of $57.28 \pm 12 \mathrm{~g}$ for oils, $177.88 \pm 29 \mathrm{~g}$ for sugars, $47.34 \pm 11 \mathrm{~g}$ for proteins and $11.28 \pm$ $3 \mathrm{~g}$ for fibers corresponding respectively to a contribution of $63.6 \%, 70.8 \%, 78.90 \%$ and $45.1 \%$ of these nutrients requirement in these women. Given that over $50 \%$ of the women surveyed were exposed to Vitamin A deficiency, there is a need for urgent intervention programs in the area to alleviate this situation.
\end{abstract}

\section{Keywords}

Vitamin A Intake, Dietary Intake, Vitamin A Deficiency, Pregnant Women, Ngaoundere

\footnotetext{
${ }^{*}$ Corresponding author.

How to cite this paper: Ngaha, D.W., Fombang, E.N. and Ejoh, R.A. (2014) Dietary Intake of Vitamin A and Macronutrients among Pregnant Women in Ngaoundere Town, Adamawa Region, Cameroon. Food and Nutrition Sciences, 5, $2071-2080$. http://dx.doi.org/10.4236/fns.2014.521219
} 


\section{Introduction}

Vitamin A deficiency (VAD) is a major public health problem in many developing countries, and malnutrition during pregnancy has been recognized as one of the major factors for high maternal and infant mortality in these countries [1]. This is because maternal VAD aggravates the other causes of maternal morbidity such as anemia in pregnancy, birth defects, blindness, increased infections and decreases of cellular differentiation [2]. VAD in children usually follows from a deficiency in the mother. Therefore, eliminating this deficiency in pregnant women will go a long way towards alleviating it in children. Several studies have shown that poor dietary patterns before and during pregnancy are among the major causes of malnutrition and VAD in most populations [3]-[5]. In addition, Vitamin A (VA) content of human breast milk is strongly affected by maternal nutrition during pregnancy and lactation [6] [7].

During pregnancy, adequate supply in Vitamin A is necessary for the growth of the fetus. Unfortunately, in many developing countries, the average daily consumption of VA by non-supplemented pregnant women is lower than the recommended daily intake [8]. The WHO report [9] reveals that approximately 54\% of pregnant women suffer from VAD in the CEMAC sub-region. A survey of available literature on the studies of VAD in Cameroon indicates that they are mostly national prevalence studies on children less than 5 years old, lacking detailed information on pregnant and lactating women, who equally constitute a vulnerable group. However, existing data shows that the Northern Regions (Adamawa, North and Far-North) are mostly affected with a prevalence rate of $62.5 \%$ in children less than 5 years old compared to the prevalence rate of $17.5 \%$ in the Southern Regions, and the national prevalence of $40 \%$ [10]. Vitamin A deficiency is also a cause for concern amongst women of child bearing age (15 - 49 years) affecting about $45 \%$ of them [10].

Addressing the problem of VAD in pregnant women will certainly go a long way towards reducing the prevalence of VAD, not only in pregnant women but also in their children. Hence, the need for this study whose objective was to evaluate the dietary intake of energy and VA among pregnant women in the town of Ngaoundere, Adamawa Region, which appears to be amongst the at risk population for VAD with a view to assisting decision makers and stakeholders design appropriate and targeted nutrition intervention programs.

\section{Material and Methods}

\subsection{Study Area}

The study took place in Ngaoundere, located in the Adamawa region of Cameroon. The Region is limited to the North by the North region, to the South by the East, Center and West regions, to the East by Central African Republic and to the West by Nigeria. There are three types of climate in the Region: an equatorial climate of Guinean type in the southern part of the Region, a tropical climate of Sudanese type on the Adamawa plateau, and an equatorial climate of Cameroonian type in the southwestern part. The high altitude gives a relatively fresh climate between 22 and 25 degrees and the annual average precipitation varies from 900 to $2000 \mathrm{~mm}$, decreasing towards the northern part of the Region.

The soil is poor and the Region sparsely populated. The principal economic activity is cattle rearing (Zebu type). However, the cultivation of tubers (Ipomea batata, Dioscorea rotundata), vegetables (Moringa oleifera, Solanum nigrum, Hibiscus sabdarifa) and cereals (Zea mays, Panicum miliaceum L.) is also practiced. Islam is the principal religion, but there are also Christians in the area. Peuls form the principal ethnic group of the Region, but there are Tikar and Gbaya strong minorities, as well as other smaller ethnic groups.

\subsection{Subjects and Sampling}

The study group comprised women at different stages of pregnancy, attending the maternity service at the Ngaoundere Regional Hospital (NRH). Patients attending this hospital come from various socioeconomic groups and from urban, semi-urban and rural areas in its catchment areas, which includes the town of Ngaoundere and some surrounding villages. Women attending this hospital are, therefore, of mixed background. Our sample population was drawn from among this group.

Pregnant women aged 40 years and below, not suffering from any infectious disease, not undergoing treatment for any disease, not on any diet, who did not use contraceptive pills prior to pregnancy and who gave their consent to be admitted in the study were recruited. Those who didn't respond to these criteria were excluded from the study. The recruitment stage lasted for two weeks at the NRH, from $17^{\text {th }}$ to $31^{\text {st }}$ March 2012. Informed 
consent was obtained from the women and the study period on the field itself lasted for one month at their residence. Ethical approval for this study was obtained from the ethical committee of the Regional Hospital in Ngaoundere.

Of the 125 subjects interviewed who had initially given their consent to participate in the study, only 100 effectively took part. Socio-demographic information was collected and anthropometric data measured for every pregnant woman. These included age, weight, height, level of education, professional status, marital status, number of children and age of pregnancy.

\subsection{Evaluation of Dietary Intake of Participants}

Subjects were interviewed at home and nutrition information was obtained using the 24 hour dietary recall method for four weeks, from $2^{\text {nd }}$ April to $3^{\text {rd }}$ May 2012. Dietary recall was done every 72 hours given that the women mostly ate the same food for about 2 days. Information on type, quantity and frequency of meals consumed was collected. A survey was also made of the culinary practices and samples of meals commonly consumed were retained for carotenoid analysis.

\subsection{Collection of Meal Samples}

Meal samples were collected in clean, tightly closed glass containers, labeled and transported in dark containers to the Food Biophysics and Nutritional Biochemistry Laboratory of the National School of Agro Industrial Sciences of the University of Ngaoundere. They were then dried at $45^{\circ} \mathrm{C} \pm 2{ }^{\circ} \mathrm{C}$ and frozen at $-20^{\circ} \mathrm{C}$. Sixteen samples were collected representing the dishes most consumed by pregnant women in Ngaoundere town.

\subsection{Extraction and Quantification of Carotenoids from the Meal Samples}

To $1 \mathrm{~g}$ of dried sample, $30 \mathrm{ml}$ of hexane-acetone mixture 30/70 (v/v) was added, and the mixture heated under reflux for one hour, cooled and filtered [11]. The filtrate was washed with distilled water in a separating funnel, the lipid phase was then decanted into a $25 \mathrm{ml}$ graduated flask and the volume adjusted to the mark with hexane. The solution obtained was diluted 1/10 with hexane and the optical density read using a spectrophotometer RAYLEIGH (VIS-723N) between 430 and $450 \mathrm{~nm}$ in order to determine the maximum optical density. Carotenoids were then quantified using of relationship:

$$
C=\frac{\left(D O_{\max } \times f\right)}{(196 \times m)}
$$

where, $D O_{\max }$ is optical density where max absorption was obtained; $f$, dilution factor; and $m$, mass of the sample.

\subsection{Estimation of Vitamin A Activity in the Meal Samples}

The VA content (Retinol Equivalent or RE) of the meals consumed was computed using the values of carotenoids determined earlier on and based on the assumption that $12 \mu \mathrm{g}$ of dietary carotenoid yields $1 \mu \mathrm{g}$ of VA activity or $1 \mu \mathrm{g}$ of dietary carotenoids equals $0.083 \mu \mathrm{g}$ RE [12] [13]. Vitamin A and proteins from animal products were obtained from Food Composition Tables [14].

\subsection{Quantification of Macronutrients in the Meal Samples}

Dry matter [15], oil [16], total proteins [17] [18], total sugars [19] and crude fibers [20] contents of meals were determined to establish their effect on VA absorption and metabolism.

\subsection{Calculation of Dietary Intakes of Pregnant Women}

Vitamin A, protein, fats, fibers and sugar intake were obtained by summing intakes coming from vegetable and animal fractions from various dishes consumed during the study period. This was obtained from the laboratory analyses of the meal samples and from food composition tables [14]. Thus, the daily VA and nutrient intake was the mean consumption per woman, per day during the period of study, and the general intake for all the studied population was the mean consumption for all the women. 


\subsection{Statistical Analysis}

The data obtained in this study was subjected to analysis of variance (ANOVA) and means separated using the least significant difference test with the statistical software Stat graphics centurion at the $5 \%$ level of significance. Microsoft Excel 2010 was used to generate the graphs. Where appropriate, percentages (\%) were calculated. Results are presented as means and standard deviation of three determinations.

\section{Results}

Table 1 shows the distribution of the studied population with respect to measured socio-demographic and anthropometric parameters. About $93 \%$ of the women were under 30 years of age. Of these $41 \%$ were teenagers between the ages of 14 and 20 years, whereas 53\% were between 21 and 30 years. In addition to their young age $37 \%$ of them had never gone to school, and only $33 \%$ had completed primary education. A small proportion (9\%) had university education. A total of $87 \%$ of these women were married with only $13 \%$ being single. Most of them however, were housewives (57\%) while $29 \%$ practiced some income generating activity (employed, petit traders, farmers). Their Body Mass Index (BMI) was generally in the normal range between 18.5 and $24.9 \mathrm{~kg} / \mathrm{m}^{2}$ (84\%). A small proportion (9\%) was undernourished with a BMI below $18.5 \mathrm{~kg} / \mathrm{m}^{2}$, and $7 \%$ were overweight with BMI above 30. About half of the women were in the first trimester of pregnancy, with $25 \%$ in the third trimester. A total of $79 \%$ of women had two or more children compared to only $21 \%$ who had at most one child.

The nutritional compositions of the sixteen dishes commonly consumed by pregnant women in Ngaoundere are presented on Table 2. Results show that vegetable dishes had high carotenoid contents with Eru (G. buchol

Table 1. Socio-demographic and anthropometric parameters of the studied population.

\begin{tabular}{|c|c|c|}
\hline Parameter & Range & Percentage of women (\%) \\
\hline \multirow{3}{*}{ Age distribution (years) } & $14-20$ & 41 \\
\hline & [21 - 30] & 52 \\
\hline & $>30$ & 07 \\
\hline \multirow{4}{*}{ Level of education } & None & 37 \\
\hline & Primary education & 33 \\
\hline & Secondary education & 21 \\
\hline & University education & 09 \\
\hline \multirow{3}{*}{ Socio-professional status } & Housewife & 57 \\
\hline & Worker & 29 \\
\hline & Student & 14 \\
\hline \multirow{3}{*}{ Body Mass Index $\left(\mathrm{kg} / \mathrm{m}^{2}\right)$} & $<18.5$ & 09 \\
\hline & [18.5 - 24.9] & 84 \\
\hline & [25 - 29.9] & 07 \\
\hline \multirow{5}{*}{ Number of children } & 0 & 10 \\
\hline & 1 & 11 \\
\hline & 2 & 39 \\
\hline & 3 & 32 \\
\hline & $\geq 4$ & 08 \\
\hline \multirow{2}{*}{ Marital status } & Married & 87 \\
\hline & Single & 13 \\
\hline \multirow{3}{*}{ Age of pregnancy } & $1^{\text {st }}$ trimester & 49 \\
\hline & $2^{\text {nd }}$ trimester & 26 \\
\hline & $3^{\text {rd }}$ trimester & 25 \\
\hline
\end{tabular}


Table 2. Nutritional composition of dishes commonly consumed by pregnant women in Ngaoundere per $100 \mathrm{~g}$ (dry basis) ${ }^{* 0}$.

\begin{tabular}{|c|c|c|c|c|c|c|c|}
\hline Dishes & Water (\%) & Oils (g) & Protein (g) & Sugars (g) & Fibers (g) & Carotenoid (mg) & $\begin{array}{l}\text { VA equivalent } \\
\text { (mg) }\end{array}$ \\
\hline Rice $^{1}+$ tomato sauce ${ }^{2}$ & $76.64 \pm 2.12^{\mathrm{de}}$ & $15.05 \pm 0.94^{\mathrm{b}}$ & $11.26 \pm 0.21^{\mathrm{b}}$ & $63.56 \pm 2.62^{\mathrm{h}}$ & $7.87 \pm 1.03^{\mathrm{cd}}$ & $11.63 \pm 0.85^{\mathrm{c}}$ & $0.97 \pm 0.07^{\mathrm{c}}$ \\
\hline Rice + roasted groundnut soup ${ }^{3}$ & $77.85 \pm 2.81 d^{\mathrm{ef}}$ & $18.21 \pm 0.37^{\mathrm{b}}$ & $12.02 \pm 0.91^{\mathrm{b}}$ & $60.01 \pm 3.12^{\mathrm{g}}$ & $7.98 \pm 0.74^{\text {cd }}$ & $1.88 \pm 0.18^{\mathrm{ab}}$ & $0.16 \pm 0.02^{\mathrm{ab}}$ \\
\hline $\begin{array}{l}\text { White sweet potato }{ }^{4} \\
\text { (boiled with flesh) }\end{array}$ & $60.38 \pm 0.83^{\mathrm{a}}$ & $2.72 \pm 0.14^{\mathrm{a}}$ & $5.01 \pm 0.38^{\mathrm{a}}$ & $81.31 \pm 2.45^{\mathrm{i}}$ & $8.23 \pm 1.04^{\text {cd }}$ & $1.64 \pm 0.17^{\mathrm{ab}}$ & $0.14 \pm 0.01^{\mathrm{ab}}$ \\
\hline Cassava fufu ${ }^{5}$ & $63.61 \pm 1.96^{\mathrm{abc}}$ & $2.00 \pm 0.11^{\mathrm{a}}$ & $4.15 \pm 0.55^{\mathrm{a}}$ & $82.78 \pm 2.84^{\mathrm{i}}$ & $8.64 \pm 1.37^{\mathrm{cd}}$ & $0.12 \pm 0.09^{\mathrm{a}}$ & $0.01 \pm 0.01^{\mathrm{a}}$ \\
\hline Rice fufu ${ }^{1}$ & $65.29 \pm 1.37^{\mathrm{bc}}$ & $1.79 \pm 0.17^{\mathrm{a}}$ & $3.84 \pm 0.39^{\mathrm{a}}$ & $81.68 \pm 3.04^{\mathrm{i}}$ & $9.69 \pm 0.85^{\mathrm{de}}$ & $0.14 \pm 0.05^{\mathrm{a}}$ & $0.01 \pm 0.00^{\mathrm{a}}$ \\
\hline White corn fufu ${ }^{6}$ & $67.15 \pm 1.14^{\mathrm{c}}$ & $3.46 \pm 0.33^{\mathrm{a}}$ & $5.56 \pm 0.74^{\mathrm{a}}$ & $81.52 \pm 3.11^{\mathrm{i}}$ & $6.88 \pm 1.01^{\mathrm{bc}}$ & $0.37 \pm 0.12^{\mathrm{a}}$ & $0.03 \pm 0.01^{\mathrm{a}}$ \\
\hline Koki $^{7}$ (with palm oil) & $64.28 \pm 3.67^{\mathrm{abc}}$ & $31.69 \pm 2.34^{\text {de }}$ & $48.89 \pm 3.05^{\mathrm{i}}$ & $13.05 \pm 1.49^{\mathrm{d}}$ & $4.17 \pm 0.77^{\mathrm{a}}$ & $35.94 \pm 1.47^{\mathrm{de}}$ & $3.00 \pm 0.12^{\mathrm{de}}$ \\
\hline Beans $^{8}$ (in cotton seed oil) & $61.74 \pm 1.98^{\mathrm{ab}}$ & $29.02 \pm 1.89^{\mathrm{cd}}$ & $44.41 \pm 2.43^{\mathrm{h}}$ & $18.15 \pm 1.21^{\mathrm{f}}$ & $5.05 \pm 0.71^{\mathrm{ab}}$ & $4.92 \pm 0.89^{\mathrm{b}}$ & $0.41 \pm 0.07^{\mathrm{b}}$ \\
\hline $\begin{array}{c}\text { Baobab leaves }^{9} \\
\text { (with local ingredients) }\end{array}$ & $87.15 \pm 3.22^{8}$ & $29.72 \pm 1.04^{\text {cd }}$ & $32.21 \pm 1.84^{\mathrm{d}}$ & $17.35 \pm 1.25^{\mathrm{f}}$ & $15.41 \pm 2.29^{g}$ & $37.59 \pm 1.25^{\mathrm{e}}$ & $3.13 \pm 0.02^{\mathrm{e}}$ \\
\hline Eru $^{10}$ (with palm oil) & $75.12 \pm 1.53^{\mathrm{d}}$ & $48.31 \pm 2.24^{\mathrm{g}}$ & $28.79 \pm 1.71^{\mathrm{c}}$ & $6.51 \pm 0.63^{\mathrm{a}}$ & $12.13 \pm 0.79^{\mathrm{ef}}$ & $81.59 \pm 3.07^{\mathrm{i}}$ & $6.80 \pm 0.26^{\mathrm{i}}$ \\
\hline Zom $^{11}$ (with groundnuts) & $81.72 \pm 2.05^{f}$ & $35.82 \pm 2.76^{\mathrm{f}}$ & $35.70 \pm 1.34^{\mathrm{ef}}$ & $9.74 \pm 0.43^{\mathrm{bc}}$ & $16.14 \pm 0.81^{\text {ghi }}$ & $40.98 \pm 2.09^{f}$ & $3.42 \pm 0.17^{\mathrm{f}}$ \\
\hline Folong ${ }^{13}$ (with groundnuts) & $81.53 \pm 3.16^{\mathrm{f}}$ & $34.02 \pm 2.39^{\mathrm{ef}}$ & $36.12 \pm 1.75^{\mathrm{f}}$ & $8.93 \pm 0.74^{\mathrm{ab}}$ & $15.76 \pm 1.32^{\mathrm{gh}}$ & $33.19 \pm 3.93^{\mathrm{d}}$ & $2.77 \pm 0.33^{\mathrm{d}}$ \\
\hline Ndole $^{12}$ (with groundnuts) & $79.35 \pm 1.79^{\mathrm{ef}}$ & $35.98 \pm 3.17^{\mathrm{f}}$ & $40.33 \pm 2.98^{\mathrm{f}}$ & $7.45 \pm 0.87^{\mathrm{ab}}$ & $12.45 \pm 2.58^{f}$ & $34.94 \pm 3.14^{\mathrm{de}}$ & $2.91 \pm 0.26^{\mathrm{de}}$ \\
\hline Fried zom ${ }^{11}$ (with tomatoes) & $78.72 \pm 2.44^{\mathrm{def}}$ & $29.96 \pm 3.01^{\mathrm{cd}}$ & $31.19 \pm 1.69^{\mathrm{cd}}$ & $16.40 \pm 0.83^{\mathrm{ef}}$ & $18.07 \pm 2.37^{\mathrm{hi}}$ & $63.30 \pm 1.04^{\mathrm{h}}$ & $5.28 \pm 0.09^{\mathrm{h}}$ \\
\hline Fried folong ${ }^{13}$ (with tomatoes) & $78.56 \pm 3.09^{\mathrm{def}}$ & $29.76 \pm 2.39^{\mathrm{cd}}$ & $32.98 \pm 1.45^{\mathrm{de}}$ & $13.99 \pm 1.24^{\mathrm{de}}$ & $18.69 \pm 1.99^{\mathrm{i}}$ & $55.39 \pm 1.51^{\mathrm{g}}$ & $4.62 \pm 0.13^{g}$ \\
\hline Fried ndole ${ }^{12}$ (with tomatoes) & $76.34 \pm 2.31^{\mathrm{de}}$ & $28.38 \pm 2.46^{\mathrm{c}}$ & $36.81 \pm 1.71^{\mathrm{g}}$ & $12.63 \pm 0.91^{\mathrm{cd}}$ & $18.73 \pm 2.69^{\mathrm{i}}$ & $57.95 \pm 2.88^{\mathrm{g}}$ & $4.83 \pm 0.24^{\mathrm{g}}$ \\
\hline
\end{tabular}

${ }^{*}$ Figures in the same column followed by the same letter are not significantly different at ( $\left.>0.05\right){ }^{\circ}$ Nomenclature of principal ingredients in meals: ${ }^{1}$ Oryza sativa; ${ }^{2}$ Lycopersicum esculentum; ${ }^{3}$ Arachis hypogea; ${ }^{4}$ Ipomea batata; ${ }^{5}$ Manihot utilissima; ${ }^{6}$ Zea mays; ${ }^{7}$ Vigna unguiculata; ${ }^{8}$ Phaseolus vulgaris; ${ }^{9}$ Adansonia digitata; ${ }^{10}$ Gnetum bucholzianum; ${ }^{11}$ Solanum nigrum; ${ }^{12}$ Vernonia amygdalina; ${ }^{13}$ Amaranthus hybridus.

zianum) (81.59 $\pm 3.07 \mathrm{mg} / 100 \mathrm{~g} \mathrm{DM})$ having the highest content followed by fried Zom (S. nigrum) with 63.30 $\pm 1.04 \mathrm{mg} / 100 \mathrm{~g} \mathrm{DM}$. Addition of tomatoes to vegetables improved carotenoid content of dishes, while addition of groundnuts improved protein content. Dishes in which palm oil was incorporated had high carotenoid content as was the case with Eru and koki. Cereals and tubers had low carotenoid contents with cassava fufu (M. utilissima) being the lowest $(0.11 \pm 0.09 \mathrm{mg} / 100 \mathrm{~g})$. Oil content in dishes varied from $2.0 \pm 0.11 \mathrm{~g}$ in cassava fufu to $48.13 \pm 2.24 \mathrm{~g}$ in Eru, proteins from $4.15 \pm 0.55 \mathrm{~g}$ in cassava fufu to $47.89 \pm 3.05 \mathrm{~g}$ in koki (V. unguiculata), fibers from $4.17 \pm 0.77 \mathrm{~g}$ in koki to $18.73 \pm 0.61 \mathrm{~g}$ in fried Ndole ( $V$. amygdalina) and finally, sugars from $6.51 \pm$ $0.63 \mathrm{~g}$ in Eru to $82.78 \pm 2.84 \mathrm{~g}$ in cassava fufu.

The quantity of animal products consumed, their VA and protein contents, were also measured (Table 3). Results show that pregnant women consumed on average 550.7g of animal proteins during the period of study, hence a daily consumption of $18.36 \mathrm{~g}$. From these foods, they obtained an estimated $1722.5 \mu \mathrm{g}$ of VA, giving a daily consumption of $57.42 \mu \mathrm{g}$ VA per pregnant woman from animal sources. This coupled with the $481.67 \mu \mathrm{g}$ from plant sources gives a total daily VA intake estimated at $539.09 \mu$ g per pregnant woman per day.

Table 4 shows the average daily macronutrient, VA and fiber intake of pregnant women in Ngaoundere. These women consume on average $539.09 \pm 43 \mu \mathrm{g}$ of VA daily, corresponding to $67.4 \%$ of their daily requirements. Apart from fibers whose daily requirements are met at only $45 \%$, the requirements for the other nutrients are met at over $60 \%$. Their total energy consumption from these nutrients stands at 1416.4 Kcal per pregnant woman per day.

Figure 1 shows the distribution of Vitamin A intake among the studied population and hence the percentage of pregnant women at risk for VAD. A total of $12.5 \%$ barely covered daily requirements in VA (>750 $\mu \mathrm{g}), 30 \%$ were exposed to slight VAD (650 - $749 \mu \mathrm{g}), 37.5 \%$ to an acute VAD (500 - $649 \mu \mathrm{g})$ and 20\% to severe VAD $(<500 \mu \mathrm{g})$. 
Table 3. Types and quantities of animal products consumed by pregnant women in Ngaoundere.

\begin{tabular}{cccc}
\hline Foods & $\begin{array}{c}\text { Average consumption } \\
\text { per woman/month }(\mathrm{g})\end{array}$ & ${\text { Proteins }(\mathrm{g})^{*}}^{*}$ & ${\text { Vitamin A }(\mu \mathrm{g})^{*}}^{*}$ \\
\hline Smoked fish & 450 & 198 & - \\
Fresh fish & 250 & 55 & 75 \\
Beef & 300 & 54 & 20 \\
Lamb mutton & 200 & 34 & - \\
Goat meat & 175 & 31.5 & 127.5 \\
Chicken & 150 & 30 & - \\
Pork & 110 & 13.2 & 1500 \\
Chicken eggs & 750 & 135 & \\
\hline
\end{tabular}

*Source: [14].

Table 4. Average daily intakes of nutrients and energy per pregnant woman in the studied population.

\begin{tabular}{ccccc}
\hline Nutrients & Intake/day & $\mathrm{RDA}^{*}$ & \% of need covered & Energy (Kcal) \\
Sugars (g) & $177.88 \pm 29$ & $250-300$ & 70.8 & 711.52 \\
Oils (g) & $57.28 \pm 12$ & $90-105$ & 63.6 & 515.52 \\
Proteins (g) & $47.34 \pm 11$ & $60-70$ & 78.9 & 189.36 \\
Fibers (g) & $11.28 \pm 3$ & $25-30$ & 45.1 & - \\
Vitamin A ( $\mu$ g) & $539.09 \pm 43$ & 800 & 67.4 & - \\
\hline
\end{tabular}

*Recommended daily allowance [21].

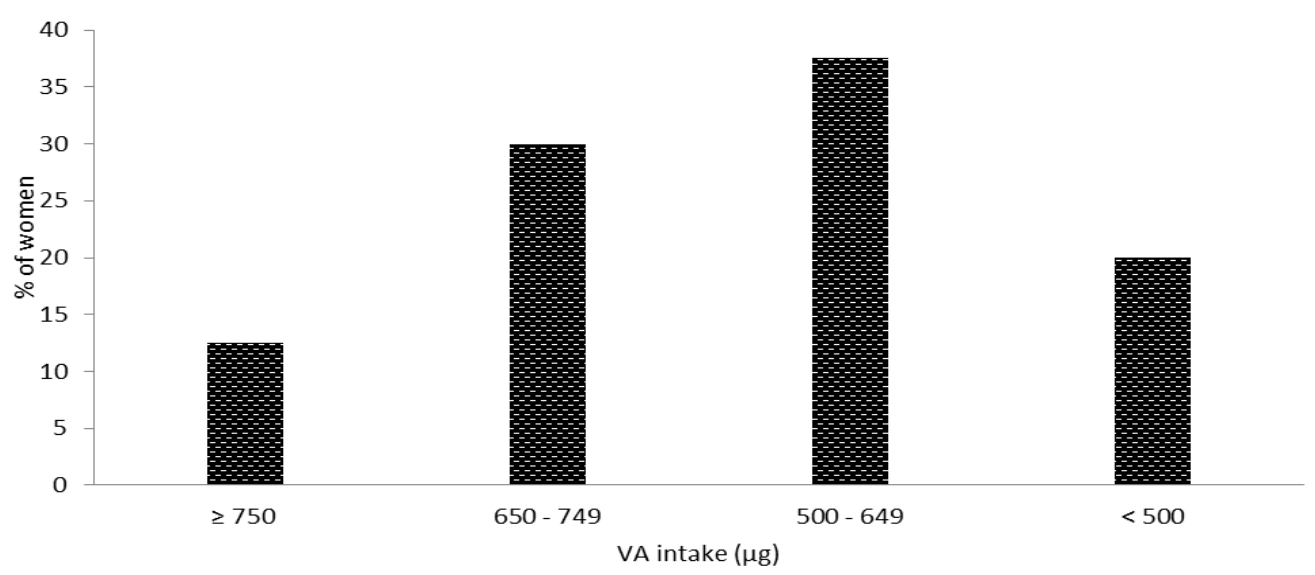

Figure 1. Classification of pregnant women according to their risk level of VAD.

\section{Discussion}

Pregnant women interviewed in this study were generally 30 years old and below (93\%), with $41 \%$ of them being teenagers 14 to 20 years old. This could be related to the fact that women in this part of the country marry early as is customary. Recent studies in the Adamawa Region [22] report that the average age of first marriage for women is 16.3 years, with 18.5 years as the mean age of first delivery. This high prevalence of teenage pregnant mothers is a cause for concern as teenage pregnancy is considered high risk given that the mother herself is still growing and has high nutrient needs, coupled with the usual pregnancy-induced changes such as hemodilution, increased urinary excretion and fetal utilization of VA, as well as a changes in the equilibrium be- 
tween the liver and blood VA [5].

The fact that these women marry early affects their education as most of them are unable to complete school. In addition, the education of the boy child is privileged over that of the girl child, reasons for the high percentage of women who never attended school (37\%) or who only succeeded in completing primary education (33\%) for those who attempted (Table 1). Previous studies had reported that in the Adamawa Region only $14.3 \%$ of girls attempt secondary education as against $24.8 \%$ for [22]). The poor educational background of these women is a hindrance to them understanding and applying nutritional policies and interventions. As a result of poor education, most of them cannot get employment and are housewives (57\%) with no income of their own, but dependent on their husbands for money to buy food and on what comes from the farms for those who do farm. Added to this, is the fact that $40 \%$ of the women studied had three or more children, who could imply reduced food intake for the mother and the children. These are risk factors for malnutrition and micronutrient deficiencies and could in part be the reason why the Adamawa Region is amongst those with a high prevalence of chronic malnutrition (40\%) [22].

In addition to cereals and tubers which are staple foods, pregnant women in Ngaoundere do consume green leafy vegetables which are rich in carotenoids; and to a minor extent animal product, some with considerable Vitamin A activity. As expected, carotenoid content was highest in green leafy vegetables dishes with values ranging from $33.19 \mathrm{mg}$ for Folong (Amaranthus hybridus) to $81.49 \mathrm{mg}$ for Eru (Gnetum bucholzianum). Variations were observed with the type of vegetable as well as the method of preparation (Table 2). Vegetables of a similar variety prepared with tomatoes had higher carotenoid content than their counterparts cooked with groundnuts. Tomatoes are a good source of $\beta$-carotene [23] and this explains the increase in carotenoid content of dishes cooked with them. Groundnuts are poor in carotenoids and in addition could have a dilution effect on the quantities of carotenoids initially present in the vegetables. The use of palm oil in the preparation of certain dishes equally improved their carotenoid content. This is the case of Eru, fried Zom and Koki. Palm oil is a rich source of $\beta$-carotene [23].

Previous studies [24] had shown that ingredients added during preparation of vegetables (oil, tomatoes, carrots) enhanced carotenoid content. These authors equally demonstrated that treatments applied to vegetables such as solar drying, blanching in water or blanching with calcium carbonate salt, significantly reduced carotenoid content of the dishes. Thus, a meal cooked directly with fresh raw vegetables should have a higher carotenoid content than a dish prepared with vegetables that have been previously treated. These findings were supported in this study as could be observed in the differences in carotenoid content of different dishes prepared with a similar type of vegetable. This could also explain in part why the results obtained in this study are higher than those reported in Burkina-Faso [25] for "Yinkum" (Solanum nigrum) and Baobab leaves (Adansonia digitata), but lower than those found by in Ivory Coast [26] for "Morelle noire" (S. nigrum) and "Amarante" (Amaranthus hybridus). In addition Vitamin A analysis in this study was carried out on the cooked dishes while in Ivory Coast, $\beta$-carotene content was determined in the raw leaf samples [26].

Pregnant women in Ngaoundere consume on average $539.09 \pm 43 \mu \mathrm{g}$ of VA daily, corresponding to $67.4 \%$ of the recommended $800 \mu \mathrm{g}$. This suboptimal consumptions shows that pregnant women of Ngaoundere are exposed to Vitamin A deficiency, and consequently to other complications like night blindness, anemia, and birth defects. This level of coverage of VA needs is similar to that of $62 \%$ found in Burkina-Faso [25] with a sample of 150 households in a village of approximately 2000 inhabitants, which is an under developed country like Cameroon. These finding attest to the high prevalence of VAD in Africa reported by WHO [9].

The high carotenoid content in the dishes containing green leafy vegetables (Table 2) could let believe that their consumption would be enough to meet the Vitamin A requirements for these pregnant women, but these values are based on dry matter. The dishes being diluted during preparation and cooking, these contents are reduced in the cooked and consumed dishes, thus unable to meet their VA requirements. For example, $100 \mathrm{~g}$ of folong cooked with groundnuts as consumed by women will bring only $511.6 \mu \mathrm{g}$ of VA. The women consume on average 65g of this soup per day, thus $332.54 \mu \mathrm{g}$ of VA, which is far from the recommended $800 \mu \mathrm{g}$ per day for pregnant women.

The average daily consumption of fats, proteins, fibers and sugar by the women were respectively $63.6 \%$, $78.9 \%, 45.1 \%$ and $70.8 \%$ of the recommended daily intake for pregnant women. The low consumption of fats could result to a reduction in the absorption of $\beta$-carotene which is fat soluble, and to a reduction in its bioconversion to VA. Studies have shown that pure $\beta$-carotene dissolved in an oily dispersion was absorbed more efficiently ( $>50 \%$ ) compared to carotenoids in raw fruits and vegetables like $\beta$-carotene of carrot or lycopene of to- 
mato which were slightly absorbed $(<3 \%)[27]$.

Food fibers reduce the bioavailability of carotenoids by trapping them, or by interacting with biliary acids having as result increase in the fecal excretion of lipids and fat-soluble substances like carotenoids [28]. Therefore, the low consumption of fibers by these women could be beneficial for their pro-Vitamin A absorption. Proteins are very important in VA metabolism. Plant proteins equally contributed to enhancing the Vitamin A status of these women. In fact retinoic acid binds to albumin at the level of intestinal mucosa to be transported in the blood [29], and VA is transported from the liver to the tissues by Retinol Binding Proteins [30]. Thus, small quantities of proteins in meals could negatively affect protein status and consequently VA absorption and transport within the body.

A total of $57.5 \%$ of the pregnant women studied were at risk for acute and severe VAD (Figure 1). This implies the majority of these women have limited access to VA sources. This rate is higher than that reported by Razafiarisoa [31] who carried out a nutritional study on VA deficiency in mothers (15 - 49 years) in Madagascar and found a prevalence rate of $29 \%$. This difference could be due to the diet that is significantly different from one country to another, as well as to climate, soils, socio-economic conditions, nutritional behaviors and food patterns. In the Adamawa Region, consumption of liver and its products, red palm oil and carrots, which are very rich in Vitamin And pro-Vitamin A, is low, due to the fact that they do not enter in the food habits of most of the population. This, therefore, could contribute to the high risk of VAD (87.5\%) among pregnant women in this region.

It is possible that the low VA and nutrient intake in this study could be related to the fact that, this study was carried out during the dry season when food crops and vegetables were scarce and expensive on the market, and as such quantities consumed in the household are reduced. Secondly, the majority of women in this study were in the first trimester of pregnancy, corresponding to a period when the amounts of cooked foods consumed may be reduced due to bouts of nausea resulting from hormonal changes in their body [32]. It is therefore necessary that this study be repeated during the rainy season when food crops and vegetables are in abundant supply and affordable, to establish seasonal variations.

\section{Conclusion}

This study reveals suboptimal dietary intake of Vitamin A, oils, proteins, fibers, sugars and energy, insufficient to cover the needs of pregnant women in Ngaoundere town. More than half of the pregnant women interviewed were exposed to acute and severe VAD and malnutrition. Thus, nutritional intervention programs should be envisaged in this area to remedy this situation as Vitamin A deficiency in the mother could lead to Vitamin A deficiency in the infant. The fact is that more than a third (41\%) of the pregnant women teenagers further aggravate the problem and call for urgent solutions.

\section{Acknowledgements}

The authors are grateful to the pregnant women who participated in this study without any financial compensation.

\section{References}

[1] Keen, C.C. (2003) The Possibility of Macronutrient Deficiencies Being Significant Contributing Factors to the Occurrence of Pregnancy Complications. Journal of Nutrition, 133, 15975-16055.

[2] Tchum, S.K., Newton, S., Tanumihardjo, S.A., Fareed, K.N.A., Tetteh, A. and Owuwu-Agyei, S. (2009) Evaluation of a Green Leafy Vegetable Intervention in Ghanaian Postpartum Mothers. AJIFAND on Line, 9, 1294-1307.

[3] Ojofeitimi, E.O., Elegbe, E. and Babatunde, J. (1982) Diet Restriction by Pregnant Women in Nigeria. International Journal of Gynaecology and Obstetrics, 20, 19-103. http://dx.doi.org/10.1016/0020-7292(82)90019-4

[4] Sasuni, R.A and Oredipe, V.A. (2002) Nutritional Status in Pregnancy and Prediction of Low Broth Weight: Evaluation of Table of Reference. Tropical Journal of Obstetrics and Gynaecology, 19, 63-67.

[5] Ima, O. Williams, Okon, U.E. and Essien, U.E. (2008) Vitamin A Status of Pregnant Women in Calabar Metropolis, Nigeria. Pakistan Journal of Biological Sciences, 11, 1702-1707. http://dx.doi.org/10.3923/pjbs.2008.1702.1707

[6] Ibrahim, K., Hassan, T.J. and Jafarey, S.N. (1991) Plasma Vitamin A and Carotene in Maternal and Cord Blood. Asia Oceania Journal of Obstetrics \& Gynaecology, 17, 159-164. http://dx.doi.org/10.1111/j.1447-0756.1991.tb00040.x 
[7] Stolzfus, R.J. and Underwood, B.A. (1995) Breast-Milk Vitamin A as an Indicator of the Vitamin A Status of Women and Infants. Bulletin of the World Health Organization, 73, 703-711.

[8] Newman, V. (1994) Vitamin A and Breast-Feeding: A Comparison of Data from Developed and Developing Countries. Food \& Nutrition Bulletin, 15, 161-176.

[9] WHO, FAO (2004) Vitamin And Mineral Requirements in Human Nutrition. 2nd Edition, Organisation Mondiale de la Santé, Genève.

[10] (2000) Enquête Nationale sur la Carence en Fer et en Vitamine A au Cameroun (ENCFVA).

[11] AOAC (1975) Methods of Analysis of the Association of Official Analytical Chemists. 10th Edition, AOAC, Washington DC.

[12] WHO (1982) Control of Vitamin A Deficiency and Xerophthalmia. World Health Organization, Geneva.

[13] National Research Council (1989) Recommended Dietary Allowances. 10th Edition, National Academy Press, Washington DC.

[14] The Food and Agriculture Organization of the United Nations (FAO) (2012) West African Food Composition Table. Rome.

[15] AFNOR (Association Française de Normalisation) (1982) Recueil des normes françaises des produits dérivés des fruits et légumes. Jus de fruits. 1ère éd., Paris la défense.

[16] Bourely, J. (1982) Observation sur le dosage de l'huile des graines de cotonnier. Coton et Fibres Tropicales, 27, 183196.

[17] AFNOR (1984) Recueil de normes françaises. Produits agricoles alimentaires: Directives générales pour le dosage de l'azote avec minéralisation selon la méthode de Kjedahl. AFNOR, Paris.

[18] Devani, M.B., Shishoo, J.C., Shal, S.A. and Suhagia, B.N. (1989) Spectrophotometrical Method for Determination of Nitrogen in Kjeldahl Digest. Journal of the Association of Official Analytical Chemists, 72, 953-956.

[19] Dubois, M., Gilles, K.A., Hamilton, J.K., Roberts, P.A. and Smith, F. (1956) Colorimetric Method for Determination of Sugar and Related Substances. Analytical Chemistry, 28, 350-356. http://dx.doi.org/10.1021/ac60111a017

[20] Wolff, J.P. (1968) Manuel d’analyse des corps gras. Azoulay éd., Paris, 519 p.

[21] Food and Nutrition Board, Institute of Medicine (2001) Vitamin A. In: Dietary Reference Intakes for Vitamin A, Vitamin K, Arsenic, Boron, Chromium, Copper, Iodine, Iron, Manganese, Molybdenum, Nickel, Silicon, Vanadium, and Zinc, National Academy Press, Washington DC, 82-146.

[22] Institut National de la Statistique (INS) et ICF International (2012) Enquête Démographique et de Santé et à Indicateurs Multiples du Cameroun 2011. Chapitres 3, 4, 5 et 10, INS et ICF International, Calverton.

[23] Claire, M.D., Barrot, L. and Philippe, C. (2001) Produits végétaux riches en carotènes: Fiches descriptives et pratiques à l'usage des pays sahéliens. Organisation Mondiale de la Santé. http://apps.who.int/iris/bitstream/10665/70499/1/WHO_NHD_01.6_fre.pdf?ua=1

[24] Djuikwo, V.N., Ejoh, R.A., Gouado, I., Mbofung, C.M. and Tanumihardjo, S.A. (2011) Determination of Major Carotenoids in Processed Tropical Leafy Vegetables Indigenous to Africa. Food and Nutrition Sciences, 2, 793-802. http://dx.doi.org/10.4236/fns.2011.28109

[25] Kossiwavi, A., Marceline, O., Claire, M.D., Alain, B. and Philippe, C. (2003) Amélioration de l'alimentation burkinabè avec des aliments riches en caroténoïdes. 2ème Atelier international, Voies alimentaires d'amélioration des situations nutritionnelles, Ouagadougou, 23-28 November 2003, 195-201.

[26] Soro, L.C., Ocho-Anin Atchibri, A.L., Armand, K.K.K. and Christophe, K. (2012) Evaluation de la composition nutritionnelle des légumes feuilles. Journal of Applied Biosciences, 51, 3567-3573.

[27] Stahl, W. and Sies, H. (1992) Uptake of Lycopene and Its Geometrical Isomers Is Greater from Heat-Processed than from Unprocessed Tomato Juice in Humans. Journal of Nutrition, 122, 2161-2166.

[28] Rock, C.L. and Swendseid, M.E. (1992) Plasma Beta-Carotene Response in Humans after Meals Supplemented with Dietary Pectin. American Journal of Clinical Nutrition, 55, 96-99.

[29] Villamor, E., Mbise, R., Spiegelman, D., Hertzmark, E., Fataki, M., Peterson, K.E., Ndossi, G. and Fawzi, W.W. (2002) Vitamin A Supplements Ameliorate the Adverse Effect of HIV-1, Malaria and Diarrheal Infections on Child Growth. Pediatrics, 109, e6. http://dx.doi.org/10.1542/peds.109.1.e6

[30] Thurnham, D.I., Northrop-Clewes, C.A., McCullough, F.S., Das, B.S. and Lunn, P.G. (2000) Innate Immunity, Gut Integrity and Vitamin A in Gambian and Indian Infants. Journal of Infectious Diseases, 182, 23-28. http://dx.doi.org/10.1086/315912

[31] Razafiarisoa, B. (2001) Enquête sur la Carence en Vitamine A chez les Femmes et les Enfants et Enquête surl’Anémie chez les Ecoliers de 6 à 14 Ans. MOST, The USAID Micronutrient Program. http://pdf.usaid.gov/pdf_docs/Pnadc603.pdf 
D. W. Ngaha et al.

[32] Wittenberg, S. (2012) Alimentation saine pour la femme enceinte. Swissmilk, Berne 143165F.

http://www.swissmilk.ch/de/shop/-dl-/fileadmin/filemount/brochures-nutritionelles-alimentation-saine-pour-la-femmeenceinte-143165-fr.pdf 
Scientific Research Publishing (SCIRP) is one of the largest Open Access journal publishers. It is currently publishing more than 200 open access, online, peer-reviewed journals covering a wide range of academic disciplines. SCIRP serves the worldwide academic communities and contributes to the progress and application of science with its publication.

Other selected journals from SCIRP are listed as below. Submit your manuscript to us via either submit@scirp.org or Online Submission Portal.
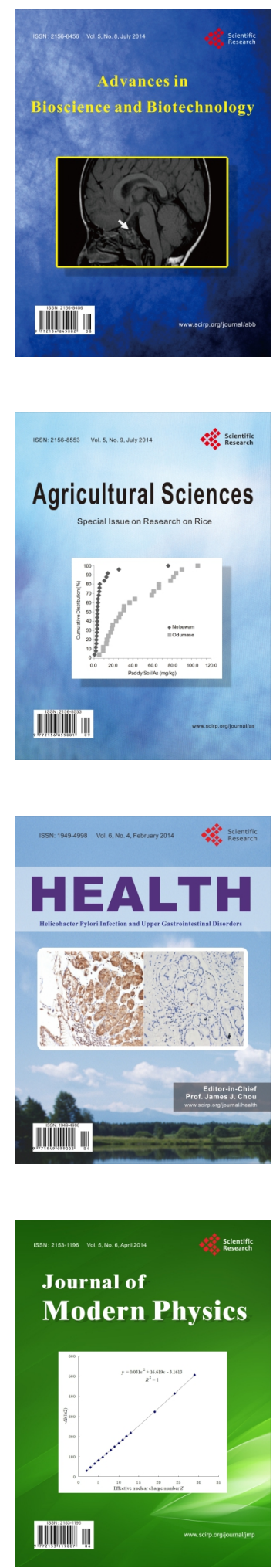
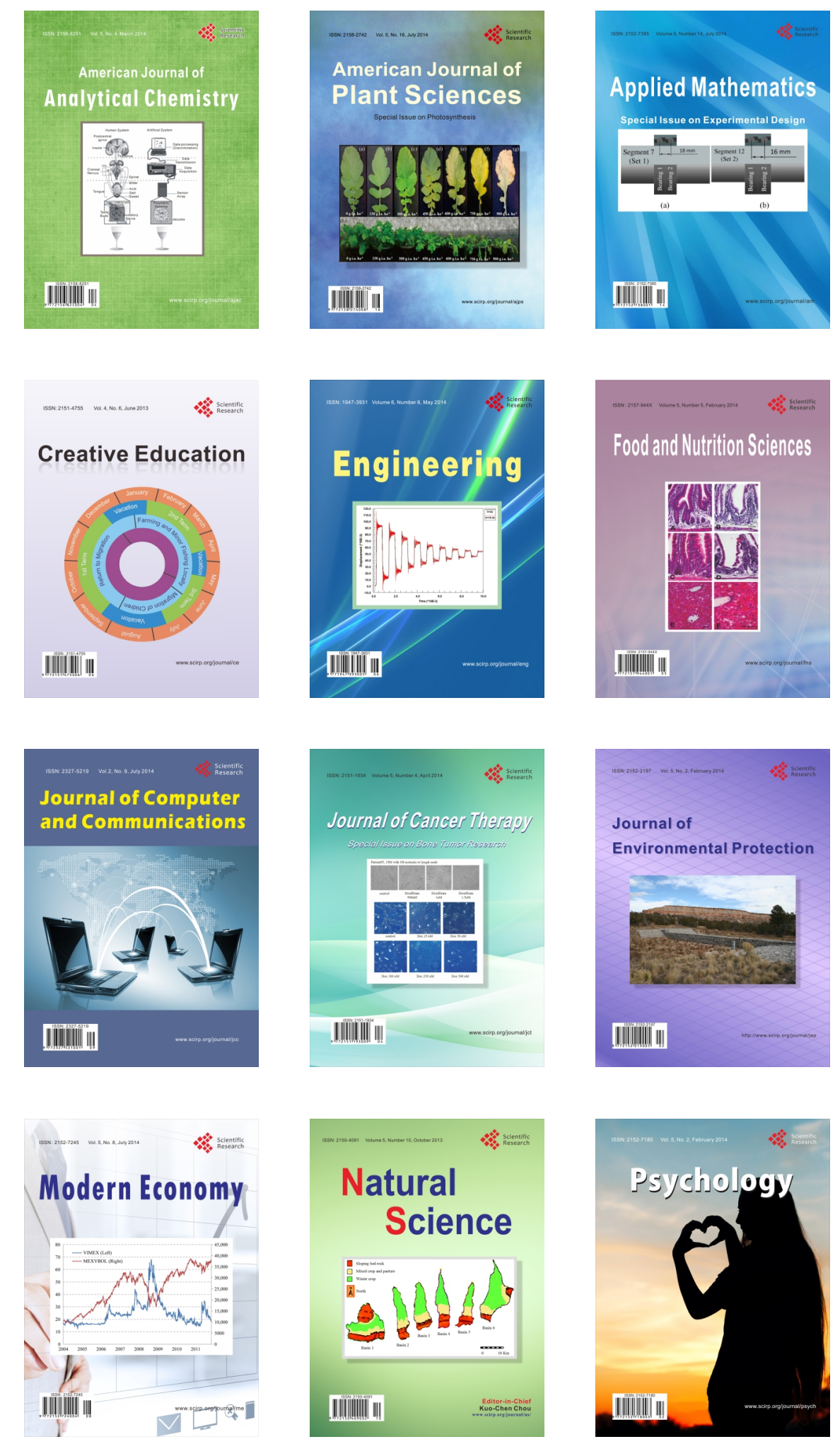